\title{
PEMELIHARAAN HUBUNGAN ANTARA ORANGTUA YANG BERCERAI DAN ANAK (STUDI KUALITATIF DESKRIPTIF KOMUNIKASI ANTARPRIBADI ANTARA ORANGTUA YANG MEMILIKI HAK ASUH DENGAN ANAKNYA)
}

\author{
Oksyta Wulandari \\ Program Studi Ilmu Komunikasi \\ Universitas Muhammadiyah Surakarta \\ Email: oksyta.wulandari@gmail.com
}

\begin{abstract}
S
Family is the smallest social unit in the society. Family also has an important role in the personal development in a child. However, today divorce rate in Indonesia has increased and divorce will harm people involved, including children. Divorce triggers weakens relationship between parent and children. In relational maintenance there are several behaviors used to maintain relational maintenance between parent and children. So the researcher was interested to know relational maintenance behaviours between divorced parents who had custody of their children with their children. In this study the researcher used qualitative research method and purposive sampling as the sampling technique. The informants were: divorced man or woman who has custody of their child and the man or woman's child. Three people were from each group were interviewed, totaling in 6 informants. The method to test data validity has source triangulation method by comparing interview and observation result from all data sources, and only selecting consistant data which has then used as data. The result of this showed that the applications of relational maintenance behaviours between parent who had custody of their children with their children consisted of several types, including positivity, openness and routine talk, assurances, task and sharing, supportiveness, joint activities, humor, and constructive conflict management. However not all relational maintenance behaviors do by divorced parents who had custody of their children with their children. Some relational maintenance behaviors performed by divorced parents who had custody of their children with their children were: positivity, supportiveness, joint activities, humor, and constructive conflict management. Meanwhile, relational maintenance behaviors that is not performed by divorced parents who had custody of their children with their children were: openness and routine talk and task and sharing that based on the lack of frequency of face-to-face between parents and children. Generally, relational maintenance performed by parent who had custody of their children with their children.
\end{abstract}

Keywords: interpersonal communication, interpersonal relationaship between parents and children, relational maintenance, divorced family

\section{A. PENDAHULUAN}

Keluarga menurut Sudarja Adiwikarta dan Sigelman \& Shaffer dalam (Yusuf, 2011) merupakan unit sosial terkecil yang bersifat universal, artinya terdapat pada setiap masyarakat di dunia (universe) atau suatu sistem sosial yang terbentuk dalam sistem sosial yang lebih, sedangkan menurut F. J Brown keluarga dalam arti sempit meliputi orangtua dan anak. Berdasarkan pada dua perspektif tersebut dapat ditarik kesimpulan bahwa keluarga terdiri dari orangtua dan anak yang merupakan unit terkecil yang ada pada setiap masyarakat di dunia. Sehingga dari definisi tersebut apabila dikaitkan dengan individu yang melakukan interaksi pertama kali dengan anak di dalam keluarga adalah orangtua, maka dari itu tidak heran 
jika akhirnya keluarga memiliki peranan penting dalam upanya mengembangkan pribadi anak (Yusuf, 2011). Selain itu Syamsu Yusuf (2011) menjabarkan beberapa fungsi keluarga meliputi: memberikan rasa memiliki, rasa aman, kasih sayang, dan mengembangkan hubungan yang baik di antara anggota keluarga. Selain itu interaski di dalam keluarga akan berpengaruh pada keharmonisan atau tidak bahagia (disharmonis) di dalam keluarga tersebut (Maryanti \& Rosmiani, 2007). Suatu keluarga dikatakan harmonis apabila struktur keluarga itu utuh dan interaksi yang berlangsung di antara anggota keluarga berjalan dengan baik, namun bila struktur keluarga itu tidak utuh lagi, misalnya karena kematian salah satu orangtua atau perceraian, maka kehidupan keluarga bisa jadi tidak harmonis lagi (Yusuf, 2011). Hal tersebut didukung oleh pendapat dari Gunarsa dalam (Maryanti \& Rosmiani, 2007) yang menyatakan bahwa keluarga yang bahagia atau ideal ditandai dengan adanya kebahagiaan yang dirasakan oleh seluruh anggota keluarga, berkurangnya ketegangan dan kekacauan, serta timbul rasa puas terhadap keadaan dan keberadaan dirinya.

Namun di Indonesia sendiri tengah marak terjadinya kasus perceraian, berdasarkan berita yang dilansir oleh portal media online health.liputan6.com pada Maret 2014 menyebutkan bahwa angka perceraianyang ada di Indonesia mengalami peningkatan yang signifikan sebesar 333 ribu per tahun (Ariyanti, 2014). Bahkan di dalam berita yang dilansir oleh republika. co.id, Menteri Sosial (Mensos) Khofifah Indar Parawansa mengungkapkan jika Jawa Timur menjadi penyumbang terbesar angka perceraian di Indonesia dengan persentase 47 persen atau hampir setengah kasus perceraian terjadi di Jawa Timur (Maharani, 2016). Perceraian dapat diartikan sebagai pecahnya suatu unit keluarga karena fungsi keluarga yang tidak berjalan dengan semestinya (Maryanti \& Rosmiani, 2007). Terjadinya perceraian karena adanya kekecewaan, sikap egois, mudah marah, dan keras kepala sehingga menimbulkan pertengakaran yang membuat pasangan suami istri merasa bahwa perkawinan yang mereka jalani tidak seperti yang mereka harapkan (Estuti, 2013).

Berbagai penelitian mengungkap dampak-dampak yang timbul dari terjadinya perceraian. Amato berpendapat bahwa perceraian berarti hilangnya manfaat yang berkaitan dengan pernikahan, meliputi memberikan dukungan emosional, persahabatan, pasangan seks yang teratur, dan keamanan ekonomi, saling mendorong dalam melaksanakan gaya hidup yang sehat dan meminimalkan perilaku yang membahayakan sepertipenggunaanalkohol atau merokok (Amato, 2012). Hal serupa juga diungkapkan oleh Prihatiningsih bahwa perceraian suami-istri seringkali berakhir menyakitkan bagi pihak-pihak yang terlibat, termasuk di dalamnya adalah anak-anak yang berimbas pada timbulnya perasaan tidak memperoleh perlindungan dan kasih sayang dari orangtuanya (Prihatinningsih, n.d.). Sedangkan oleh Rodger dan Pryor dengan mengulas studi yang sebanding dari Inggris, Kanada, Australia, dan New Zealand yang secara umum menunjukkan bahwa anak-anak dengan orangtua yang bercerai memiliki perilaku masalah, memiliki masalah emosional, memperoleh tes akademik dan nilai sekolah yang lebih rendah, dan memiliki banyak masalah dibanding anak-anak dengan orangtua yang tidak bercerai (Amato, 2012). Bahkan penelitian yang dilakukan oleh B. C Feeny dan Monin menunjukkan bahwa remaja yang berasal dari keluarga yang bercerai merasa tidak aman dengan rekannya yang berasal dari keluarga yang utuh (Fraley \& Heffernan, 2013). Selain itu perceraian juga akan berdampak pada interaksi yang terjalin antara orangtua dan anak (Maryanti \& Rosmiani, 2007). Pendapat ini didukung oleh Fagan dan Chrunchill bahwa perceraian menyebabkan kerusakan untuk semua yang terlibat terutama untuk anakanak dan secara permanen melemahkan keluarga serta hubungan antara anak-anak dengan orangtuanya (Fagan \& Churchill, 2012). 
Terkaittentang hubungan, beberapa ahli mengemukakan mengenai pemeliharaan hubungan. Salah satunya adalah Canary yang telah mendefinisikan pemeliharaan hubungan menjadi empat definisi, meliputi: relationalmaintenance in existence, relational maintenance in a specific state, relational maintenance in a satisfactory condition, dan relational maintenance in repair. Dia juga merumuskan bahwa terdapat lima perilaku pemeliharaan hubungan yang meliputi: positivity (interaksi yang menyenangkan), openness (keterbukaan), task and sharing (pembagian tugas bersama), assurances (memberikan komitmen pada hubungan), dan social networking (menghabiskan waktu bersama dengan lingkungan sosial patner). Sedangkan Guererro di dalam bukunya menambahkan beberapa perilaku pemeliharaan hubungan lainnya untuk melengkapi perilaku pemeliharaan hubungan oleh Canary, meliputi: openness and routine talk (saling berbicara dan mendengarkan satu sama lain), supportiveness (saling memberikan dukungan dan dorongan), joint activities (saling menghabiskan waktu bersama dengan patner), romance and affection (peduli terhadap perasaan satu sama lain), humor (saling menggunakan lelucon dalam berhubungan), dan constructive conflict management (menyelesaikan konflik dengan baik). Dindia dalam (Galvin, Braithwaite, \& Bylund, 2016) menambahkan bahwa untuk menjaga kualitas hubungan maka kualitas dari komunikasi harus dijaga, karena berbicara merupakan inti dari relational maintenance. Pengaplikasian pemeliharaan hubungan dalam suatu hubungan akan menimbulkan kepuasan di dalam suatu hubungan yang sama halnya ketika kita memperoleh kesenangan dalam hubungan yang kita jalani (Guerrero, Andersen, \& Afifi, 2004). Sehingga peneliti tertarik untuk mengetahui bagaimana perilaku pemeliharaan hubungan antara orangtua yang bercerai yang memiliki hak asuh dengan anaknya.

\section{B. TELAAH PUSTAKA}

\section{Hubungan Antarpribadi dalam Komu- nikasi Antarpribadi}

Menurut Bochner, Capella, dan Miller dalam (Devito, 2011) menyatakan bahwa para ahli teori komunikasi mendefinisikan komunikasi antarpribadi dengan berbeda beda. Devito menjelaskan mengenai tiga pendekatan utama dalam mendefinisikan komunikasi antarpribadi yaitu berdasarkan komponen, hubungan diadik, dan pengembangan. Lebih lanjut menurut Devito bahwa berdasarkan hubungan diadik komunikasi antarpribadi adalah komunikasi yang berlangsung di antara dua orang yang mempunyai hubungan yang mantap dan jelas. Komunikasi menjadi salah satu cara terpenting yang digunakan untuk membangun sebuah hubungan antarpribadi. Hal serupa juga diungkapkan oleh Kuntaraf dalam (Wijayanti, 2013) bahwa berbicara merupakan elemen yang paling penting dalam sebuah hubungan. Berger dalam (Abadi, Sukmawan, \& Utari, 2013) menambahkan bahwa komunikasi antarpribadi menjadi bentuk komunikasi yang paling sering digunakan untuk saling berinteraksi baik secara aktif, pasif, ataupun interaktif. Selain itu komunikasi antarpribadi dibangun atas dasar pemenuhan kebutuhan manusia yaitu sebagai makhluk sosial karena dengan menggunakan komunikasi antarpribadi membuat seseorang dapat membangun hubungan sosial dengan sesamanya, baik itu anggota keluarga, teman, ataupun orang-orang yang dianggap penting serta berpengaruh di dalam kehidupan dirinya (Abadi et al., 2013).

Berger, Daiton, dan Stafford dalam (West \& Turner, 2008) menambahkan bahwa di dalam konteks komununikasi antarpribadi banyak membahas mengenai suatu hubungan serta tentang keretakan dari suatu hubungan. Lebih lanjut Devito mengungkapkan bahwa manusia tidak bisa lepas dari hubungan. Hal tersebut didukung dengan penjelasannya bahwa ketika kita tidak berhubungan dengan orang lain dalam waktu yang lama maka akan berdampak pada timbulnya rasa tertekan dan rasa ragu pada diri kita sendiri, 
selain itu kita juga akan merasa sulit untuk dapat menjalani kehidupan sehari-hari (Devito, 2011). Desmon Morris dalam Devito (2011) mendukung penjelasan dari Devito bahwa kontak dengan orang lain begitu penting, sehingga sering kali orangorang mengunjungi profesional seperti dokter, perawat, dan pemijat bukan karena mereka menderita sakit fisik, namun karena adanya kebutuhan untuk melakukan kontak dengan orang lain. Selain itu penggunaan komunikasi antarpribadi dirasa lebih cocok untuk memberikan perasaan positif terhadap diri sendiri maupun terhadap orang lain, hal tersebut di dasari oleh pendapat dari Fajar (2009) bahwa diperlukan adanya komunikasi antarpribadi untuk dapat mengurangi rasa kesepian dan ketegangan serta untuk membuat seseorang agar merasa positif terhadap dirinya sendiri.

Devito (2011) mengungkapkan di dalam bukunya bahwa hubungan antarpribadi dapat dijelaskan dengan mengindentifikasi dua karakteristik penting. Pertama, hubungan antarpribadi berlangsung melalui beberapa tahap yang berawal dari tahap interaksi awal hingga terjadinya pemutusan. Kedua, hubungan antarpribadi berbedabeda terkait tentang hal keleluasaan dan kedalamannya. Lebih lanjut Devito dalam (Abadi et al., 2013) menjelaskan bahwa hubungan antarpribadi adalah hubungan yang terjadi di antara dua individu atau lebih. Sedangkan Knapp dan Wood dalam (Devito, 2011) menyatakan bahwa kebanyakan atau bahkan mungkin semua hubungan dapat berkembang dengan melalui beberapa tahap. Namun kita tidak mungkin menjadi kawan yang dapat akrab satu sama lain segera setelah pertemuan pertama kita terjadi. Pada dasarnya kita secara bertahap akan menumbuhkan keakraban dengan melalu beberapa tahapan ataupun langkah. Devito menambahkan bahwa terdapat lima tahap dalam pengembangan hubungan, meliputi: kontak, keterlibatan, keakraban, perusakan, dan pemutusan. Kelima tahapan ini tidak untuk mengevaluasi ataupun menguraikan bagaimana seharusnya hubungan itu berlangsung, melainkan untuk menggambarkan hubungan seperti apa adanya.

Tahap pertama, kontak yang menjelaskan bahwa pada tahap ini kita akan menggunakan beberapa persepsi alat indra meliputi: melihat, mendengar, dan membaui seseorang. Beberapa peneliti mengungkapkan bahwa pada tahap ini yaitu pada empat menit pertama menjadi penentu apakah kita akan melanjutkan hubungan yang sedang kita jalani atau tidak. Hal tersebut karena pada tahap ini penampilan fisik menjadi begitu penting, karena dimensi fisik paling terbuka untuk diamati dengan mudah. Meskipun demikian pada tahap ini pula kualitas-kualitas lain misalnya seperti sikap bersahabat, kehangatan, keterbukaan, dan dinamisme juga dapat terungkap. Apabila pada tahap ini, kita menyukai orang yang sedang menjalin hubungan dengan kita maka kita akan melanjutkan ke tahap kedua (Devito, 2011).

Tahap kedua, keterlibatan yaitu tahap dimana kita melakukan pengenalan lebih jauh kepada orang lain yang menjalin hubungan dengan kita. Pada tahap inilah kita mulai untuk mengungkapkan diri kita. Devito mencontohkan bahwa jika hubungan yang sedang terjalin bersifat romantik maka kita akan melakukan kencan pada tahap ini, sedangkan apabila hubungan ini adalah hubungan persahabatan maka kita akan pergi bersama ke bioskop atau pergi ke pertandingan olahraga bersamasama. Bahkan Tolhuizen dalam (Devito, 2011) mengungkapkan bahwa dia telah meneliti mengenai strategi yang digunakan oleh pasangan yang berkencan untuk menguatkan hubungan mereka dan melangkah ke tahap ketiga yaitu keakraban (Devito, 2011).

Tahap ketiga, keakraban yaitu tahap dimana kita akan mengikatkan diri kita lebih jauh kepada orang lain yang sedang menjalin hubungan dengan kita. Bahkan ada kemungkinan bila kita akan membina hubungan primer dengannya misalnya menjadi sahabat baik ataupun menjadi seorang kekasih. Selain itu pada tahap ini kita akan dapat mengungkapkan rahasia 
terbesar kita. Namun, tidak banyak yang dapat mencapai tahap ini karena pada tahap ini hanya disediakan hanya untuk beberapa orang saja. Hal tersebut karena jarang bagi seseorang untuk memiliki lebih dari empat orang sahabat yang akrab dengannya kecuali di dalam lingkup keluarga (Devito, 2011).

Tahap keempat, perusakan adalah tahap dimana ikatan di antara kedua belah pihak melemah atau dapat dikatakan bahwa pada tahap ini terjadi penurunan hubungan. Pada tahap ini kita akan mulai merasa bahwa hubungan yang sedang kita jalani ini tidak sepenting seperti yang kita pikirkan sebelumnya. Dampak dari terjadinya perusakan hubungan adalah kita yang akan semakin menjauh dari orang lain yang tengah menjalin hubungan dengan kita. Dampak lain yang muncul adalah kita juga tidak memiliki cukup waktu untuk dapat menghabiskan waktu berdua, dan ketika kita bertemu maka kita hanya akan saling diam dan tidak banyak melakukan pengungkapan diri. Hal tersebut mendukung pernyataan Baxter dalam (Devito, 2011) yang mengungkapkan bahwa bila suatu hubungan mulai rusak, maka keluasan dan kedalaman akan berbalik arah dengan sendirinya yang berdampak pada hilangnya topik pembicaraan tertentu, dangkalnya pembahasan suatu topik, mengurangi tingkat pengungkapan diri, dan mengurangi tingkat pengungkapan perasaan yang paling dalam (Devito, 2011).

Tahap kelima, pemutusan yaitu tahap terakhir dan merupakan tahap dimana terjadi pemutusan ikatan yang mempertalikan kita dengan orang lain yang menjalin hubungan dengan kita. Jika bentuk ikatan tersebut adalah perkawinan, maka pemutusan hubungan adalah dengan perceraian. Dijelaskan juga bahwa pada tahap inilah ketika harta kekayaan dibagi dan pasangan suami istri saling bertarung memperebutkan hak asuh anak. Namun pada tahap ini juga tidak menutup kemungkinan sebagai awal bagi keduanya untuk dapat memulai dan membina kehidupan yang baru (Devito, 2011).
Pada tahap awal suatu hubungan umumnya ditandai dengan kesempitan dan kedangkalan terhadap topik yang sedang dibahas. Hal tersebut karena apabila ketika kita pada pertemuan pertama membahaas topik secara mendalam maka akan timbul rasa ketidaknyamanan. Devito (2011) menambahkan bahwa dalam melakukan tahapan hubungan antarpribadi terkadang ada kalanya kita telah membina hubungan yang intim namun kita tidak ingin mempertahankannya lagi. Namun kita juga sudah merasa puas dengan hubungan yang sedang kita jalani sehingga kita tidak ingin bila hubungan itu rusak, maka langkah tepat yang kita ambil adalah dengan kembali ke tahap keterlibatan dan tidak masuk ke dalam tahap keakraban. Lebih lanjut Altman dan Taylor dalam (Devito, 2011) menyatakankan bahwa hubungan juga dapat diuraikan berdasarkan jumlah topik yang dibicarakan oleh dua orang serta derajat kepersonalan yang mereka lekatkan pada topik-topik yang mereka bahas. Banyaknya topik yang mereka bicarakan ketika berhubungan disebut keluasan, sedangkan derajat kepersonalan disebut kedalaman. Devito mengilustrasikan hubungan individu sebagai suatu lingkaran dan membagi lingkaran tersebut menjadi bagian-bagian laba-laba. Dia lalu membuat tiga lingkaran yang berbeda untuk menggambarkan tingkat keluasan dan kedalam dalam suatu hubungan. Pada lingkaran pertama adalah hubungan yang mungkin kita miliki dengan kenalan, karena pada interaksi ini hanya membahas topik yang sedikit serta bersifat dangkal. Pada lingkaran kedua adalah hubungan yang mungkin kita miliki dengan seorang kawan karena pada interaksi ini kita akan lebih dalam dalam membahas mengenai topik dan jumlah topik yang dibahas juga lebih banyak daripada sebelumnya. Sedangkan pada lingkaran ketiga adalah hubungan yang kita miliki dengan kekasih, orangtua, atau saudara kandung, karena pada interaksi ini kita membahas topik yang jumlahnya lebih banyak dibanding sebelum-sebelumnya dan sebagian besar topik dibahas dengan lebih mendalam (Devito, 2011). 


\section{Pemeliharaan hubungan dalam Komu- nikasi Antarpribadi}

Ketika seseorang memilih untuk melakukan komunikasi antarpribadi, maka ada tujuan yang ingin diperoleh. Seperti yang diungkapkan oleh Fajar (2009) di dalam bukunya yang berjudul "Ilmu Komunikasi Teori \& Praktek" yang menyebutkan terdapat enam tujuan komunikasi antarpribadi meliputi: pertama, untuk mengenal diri sendiri karena komunikasi antarpribadi dapat memberikan kesempatan bagi kita untuk membahas tentang diri kita sendiri, belajar tentang bagaimana dan sejauh mana kita harus membuka diri terhadap orang lain, serta membuat kita mengerti nilai, sikap, dan perilaku orang lain; kedua, untuk mengetahui dunia luar karena nilai keyakinan, sikap dan perilaku kita lebih banyak dipengaruhi oleh komunikasi antarpribadi yang telah kita jalin dibandingkan pengaruh dari media massa dan pendidikan formal; ketiga untuk menciptakan dan memelihara hubungan menjadi bermakna karena pada dasarnya manusia terlahir sebagai makhluk individu sekaligus sosial sehingga dalam kehidupan sehari-hari kita ingin menciptakan dan memelihara hubungan dengan orang lain, selain itu kita juga tidak ingin hidup terisolasi dari masyarakat, ingin merasakan dicintai dan mencintai, serta juga ingin disukai dan menyukai orang lain; keempat untuk mengubah sikap dan perilaku karena dengan komunikasi antarpribadi kita sering kali berusaha untuk mempersuasi orang lain agar mengubah sikap dan perilakunya; kelima, untuk bermain dan mencari hiburan hal ini terkait dengan memperoleh suasana lepas dari dilakukannya komunikasi antarpribadi; keenam, adalah untuk membantu misalnya komunikasi antarpribadi yang dilakukan oleh seorang psikiater terhadap pasiennya.

Pemeliharaan hubungan (relational maintenance) nyatanya menjadi salah satu tujuan seseorang untuk melalukan komunikasi antarpribadi. Guerrerro, Andersen, \& Afifi (2004) menambahkan bahwa hubungan juga tidak akan dapat terjalin kecuali terdapat dua orang untuk saling berkomunikasi satu sama lain. Lebih lanjut Dindia dan Canary dalam (Guerrero, Andersen, \& Afifi, 2004), mendefinisikan pemeliharaan hubungan dalam empat definisi. Pertama, pemeliharaan hubungan in existence yaitu melibatkan cara untuk menjaga hubungan yang sudah ada; kedua, relational maintenance in a specific state yaitu melibatkan cara menjaga hubungan pada kondisi atau bentuk tertentu, atau dalam level keiintiman yang stabil, sehingga status quo dapat dipertahankan; ketiga, relational maintenance in a satisfactory condition yaitu melibatkan cara menjaga hubungan pada kondisi yang saling memuaskan kedua belah pihak; keempat, relational maintenance in repair yaitu melibatkan cara dalam menjaga suatu hubungan yang dalam proses perbaikan. Inti dari keempat definisi yang telah dikemukaan oleh Dindia dan Canary menjelaskan bahwa di dalam melakukan perilaku pemeliharaan hubungan memungkinkan mitra relational untuk menjaga hubungan mereka dalam level kedekatan sehingga mereka dapat menemukan kepuasan di dalam hubungan yang sedang mereka jalani (Valley \& Gilman, 2009). Hal serupa juga diungkapkan oleh Stafford, Weigel, dan Ballard-Reich bahwa orang yang melakukan usaha pemeliharaan hubungan akan merasa puas dengan hubungan mereka dimana kepuasan dalam sutu hubungan menurut Vangelesti dan Huston adalah kesenangan dan kebahagiaan yang orang peroleh dari hubungan mereka (Guererro, Anderson, \& Afifi, 2004). Lebih lanjut Canary, Stafford, Hause, dan Wallace dalam (Valley \& Gilman, 2009) berpendapat perilaku pemeliharaan hubungan juga membantu menjaga kepuasan dalam hubungan di dalam keluarga meskipun ada perbedaan secara spesifik ketika digunakan pada hubungan romantis.

Dalam penelitian ini peneliti lebih berfokus pada perilaku pemeliharaan hubungan yang dikemukakan oleh Guererro. Hal tersebut karena di dalam perilaku pemeliharaan oleh Guererro terdapat perilaku yang tidak dijelaskan sebelumnya oleh teori terdahulu namun 
memiliki keterkaitan dengan pemeliharaan hubungan, sehingga dapat dikatakan bahwa perilaku pemeliharaan oleh Guererro melengkapi perilaku pemeliharaan hubungan yang telah ada sebelumnya. Salah satu perilaku pemeliharaan yang dikemukakan oleh Guererro adalah berkenaan dengan penyelesaian konflik dengan baik, perilaku ini awalnya tidak termasuk dalam perilaku pemeliharaan hubungan yang terdahulu. Namun penyelesaian konflik memiliki keterkaitan dengan pemeliharaan hubungan dalam keluarga. Hal ini didukung oleh pendapat dari Dunn dan Slomkowski bahwa konflik merupakan aspek utama di dalam pengembangan hubungan antara orangtua dengan anak. Sedangkan Blum-Kulka dan Snow dalam mengatakan bahwa anak akan belajar bermacam-macam pelatihan komunikasi seperti pemeliharaan hubungan dan pengelolaan konflik melalui interaksi di dalam keluarga (Valley \& Gilman, 2009). Perilaku pemeliharaan hubungan yang dikemukakan oleh Guererro, Andersen, dan Afifi meliputi: positivity yang berkaitan dengan terjalinnya interaksi yang menyenangkan; openness and routine talk yang menekankan pada perilaku untuk saling berbicara dan mendengarkan satu sama lain; task and sharing yaitu melakukan pembagian tugas bersama; assurances yang berkaitan tentang membarikan komitmen pada hubungan; social networking adalah dengan menghabiskan waktu bersama dengan lingkungan sosial patner; supportiveness yaitu untuk saling memberikan dukungan dan dorongan; joint activities adalah perilaku menghabiskan waktu bersama dengan patner; romance and affection yang berkitan dengan kepedulian terhadap perasaan satu sama lain; humor adalah perilaku dengan saling menggunakan lelucon dalam berhubungan; dan constructive conflict management adalah perilaku dalam menyelesaikan konflik dengan baik (Guerrero, Andersen, \& Afifi, 2004). Dalam penelitian yang dilakukan oleh Bippus dan Rollin, Guerrero dan Bachman, serta Simondan Baxter dalam (Valley \& Gilman, 2009) mengungkapkan bahwa pembicaraan yang ringan dan rutinitas dalam berhubungan juga memungkinkan menjadi cara untuk menjaga hubungan antara anak dengan dengan orangtua. Bahkan Sillars, Canary, dan Tafoya mengadakan sebuah telaah pustaka mengenai konflik keluarga dan menurut mereka antara orangtua dan anak akan lebih merasakan kepuasan terhadap hubungan yang mereka jalani apabila konflik yang terjadi dapat ditangani dengan baik di dalam keluarga.

\section{METODE}

Pada penelitian ini peneliti menggunakan metode penelitian kualitatif. Alasan peneliti menggunakan metode ini karena dalam penelitian ini peneliti ingin mengetahui bagaimana perilaku pemeliharaan hubungan yang terjadi antara orangtua yang bercerai yang memiliki hak asuh dengan anaknya. Sehingga dalam proses pengumpulan data peneliti akan melakukan wawancara mendalam kepada sumber data sehingga memperoleh data yang mendalam dari sumber data tersebut. Seperti yang diungkapkan oleh Sugiyono bahwa metode kualitatif digunakan untuk memperoleh data mendalam yang mengandung makna, makna dalam hal ini adalah data yang sebenarnya, data yang pasti merupakan suatu nilai di balik data yang tampak (Sugiyono, 2013).

Dalam penentuan sampel yang akan digunakan untuk memperoleh data, peneliti akan menggunakan teknik purposive sampling. Purposive sampling yaitu teknik pengambilan sampel sumber data dengan pertimbangan tertentu, misalnya: orang tersebut dianggap paling mengetahui tentang apa yang peneliti harapkan, sebagai penguasa sehingga akan memudahkan peneliti menjelajah objek/ situasi sosial yang diteliti (Sugiyono, 2013). Penentuan kriteria dari sampel tersebut berdasarkan dari tujuan yang ingin peneliti capai dalam penelitian ini. Peneliti mengambil sampel penelitian dengan kriteria tertentu yaitu: suami atau istri yang telah bercerai dan 
memiliki hak asuh atas anaknya serta anak dari suami atau istri tersebut, masing-masing sebanyak 3 orang, sehingga diperoleh informan sebanyak 6 orang. Alasan peneliti menggunakan keluarga bercerai sebagai objek penelitian karena banyak penelitian yang menjelaskan bahwa terdapat berbagai dampak negatif yang bermunculan terhadap hubungan antara orangtua dan anak pasca terjadinya perceraian di dalam keluarga.

Namun dalam penelitian ini peneliti hanya berfokus untuk memperoleh data dari orangtua yang memiliki hak asuh terhadap anak dan anaknya saja. Hal tersebut karena perilaku pemeliharaan hubungan dengan anak akan lebih efektif ketika terjalin dengan orangtua yang memiliki hak asuh daripada orangtua yang tidak memiliki hak asuh. Pendapat ini didasari oleh sebuah penelitian yang menjelaskan bahwa dengan terjadinya perceraian akan berpengaruh terhadap frekuensi bertemu dan intensitas interaksi antara orangtua yang tidak tinggal seatap dengan anaknya setelah perpisahan mereka, sehingga hal tersebut berakibat menimbulkan kerenggangan dan kekakuan karena jarang bertemu (Maryanti, 2007).

Tujuan dalam penelitian ini adalah untuk mengetahui bagaimana perilaku pemeliharaan hubungan yang dilakukan antara orangtua yang bercerai yang memiliki hak asuh dengan anaknya. Perilaku pemeliharaan hubungan yang peneliti digunakan dalam penelitian ini adalah perilaku pemeliharaan hubungan oleh Guererro. Pada proses pengumpulan data peneliti akan melakukan wawancara mendalam dan semi terstuktur serta melakukan observasi non partisipan untuk memperoleh data. Selanjutnya, untuk menganalisis data penelitian. peneliti akan menggunakan teknik analisis data model Miles and Huberman yaitu analisis yang dilakukan secara interaktif dan berlangsung secara terus menerus sampai tuntas, sehingga datanya sudah jenuh. Pada penelitian ini aktivitas dalam analisis data meliputi: data reduction yaitu peneliti akan melakukan pemilihan data penting dari hasil transkip wawancara yang dilakukan oleh peneliti, data display yaitu peneliti akan membentuk uraian singkat dalam bentuk naratif berdasarkan data-data penting yang telah direduksi sebelumnya, sehingga akan memudahkan peneliti untuk memahami dan merencakan langkah penelitian selanjutnya, dan conclusion drawing/ verification pada tahap ini peneliti akan melakukan kategorisasi data yang telah penulis peroleh. Cara pengkategorisasian data adalah berdasarkan perilaku yang perlu digunakan untuk menjaga hubungan dalam komunikasi yang terjalin antara orangtua yang bercerai yang memiliki hak asuh dengan anaknya meliputi: Positivity (interaksi yang menyenangkan), Openess and routine talk (keterbukaan dan rutin berkomunikasi), Assurances (jaminan komitmen), Task and Sharing (pembagian tugas), Supportiveness (dukungan), Joint activities (kegiatan bersama), Humor (kelucuan), dan Constructive Conflict management (manajemen konflik dengan baik).

Untuk menguji keabsahan data, peneliti menggunakan metode triangulasi, Sugiyono menyatakan bahwa dengan menggunakan teknik triangulasi dalam pengumpulan data, maka data yang diperoleh akan lebih konsisten, tuntas, dan pasti. Pendapat ini didukung oleh Patton yang mengatakan bahwa dengan triangulasi akan lebih meningkatkan kekuatan data bila dibandingkan dengan satu pendekatan (Sugiyono, 2013). Dalam penelitian ini peneliti menggunakan triangulasi sumber data. Triangulasi sumber data yang akan peneliti lakukan adalah dengan membandingkan hasil wawancara dan observasi yang diperoleh dari seluruh sumber data dan hanya memilih data-data yang bersifat konsisten yang selanjutnya akan digunakan sebagai data penelitian yang pasti.

\section{HASIL DAN PEMBAHASAN}

Perilaku pemeliharaan antara orangtua yang bercerai yang memiliki hak asuh 
dengan anaknya menurut perilaku pemeliharaan hubungan oleh Guererro, Andersen, dan Afifi, meliputi:

\section{Positivity (Interaksi yang Menyenang- kan)}

Positivity adalah perilaku pemeliharaan hubungan yang membuat terciptanya interaksi yang menyenangkan di antara orangtua dan anak. Interaksi yang dilakukan berlangsung dengan positif, baik orangtua maupun anak dapat menciptakan suasana yang nyaman ketika berkomunikasi. Sebagai seorang anak, mereka dapat memberikan kenyamanan ketika berinteraksi dengan orangtuanya meskipun hanya dengan menanggapi ketika orangtuanya sedang berbicara dengan dia secara baik-baik. Sebagai sosok orangtua mereka dapat memposisikan diri mereka sebagai teman bagi anak, hal tersebut mereka lakukan agar anak merasa nyaman untuk menjalin komunikasi dengan orangtua. Kenyamanan tersebut menurut orangtua akan berdampak pada munculnya sikap terbuka, sehingga anak akan leluasa untuk bercerita kepada orangtua mengenai permasalahan yang sedang dihadapi. Meskipun demikian orangtua juga bersikap tegas kepada anaknya dalam hal-hal tertentu, sehingga anak juga tidak berbuat melanggar batasan. Tetapi dalam menunjukkan ketegasannya, orangtua memilih untuk tidak berbicara kasar terhadap anak, karena dengan berbicara kasar terhadap anak akan membuat anak menghindar dan menjauh dari mereka, selain itu anak juga menjadi memiliki sikap membangkang. Seperti yang disampaikan oleh seorang informan:

"Ya, karena sayang, istilahe sama (istilahnya dengan) anak sendiri, kalau dikasarin efeknya kan jadi jauh. Trus (terus) kadang dikasarpun jadinya juga kurang bagus". (Wawancara dengan informan 1/Pa. Tanggal 24 Mei 2016).

Dampak dari terciptanya komunikasi yang menyenangkan antara orangtua dan anak membuat anak merasa nyaman dan senang untuk berkomunikasi dengan orangtua mereka. Ketika terjalin komunikasi yang menyenangkan di dalam keluarga maka anak merasa aman, terlebih lagi ketika orangtua dapat memposisikan dirinya sebagai teman bagi anak maka dia akan lebih leluasa dan terbuka dalam menyampaikan semua permasalahan yang dia hadapi (Widayati et al., n.d.). Bahkan Morr Serewicz, Dickson, Morrison, dan Poole menegaskan bahwa anak muda akan merasa lebih puas terhadap hubungan keluarganya ketika di dalam keluarga tersebut menggunakan positivity yang tinggi (Guerrero, Andersen, \& Afifi, 2004). Walgito dalam (Widayati et al., n.d.) menjelaskan bahwa kualitas hubungan antara orangtua dan akan mempengaruhi cara anak melihat dirinya sendiri yang akan berdampak pada munculnya sikap puas dan tidak puas.

\section{Openness and routine talk (Keterbu- kaan dan Rutin Berkomunikasi)}

Openness and routine talk adalah perilaku pemeliharaan hubungan yang menekankan pada keterbukaan serta saling berbicara dan mendengarkan dengan rutin. Dari hasil observasi dan wawancara dengan informan menunjukkan bahwa baik orangtua maupun anak memiliki tingkat keterbukaan diri yang rendah. Namun salah satu dari informan anak mengungkapkan bahwa dia dapat terbuka kepada orangtuanya karena memang sudah dididik dari kecil untuk selalu terbuka. Rendahnya keterbukaan diri yang dilakukan anak kepada orangtua karena rendahnya frekuensi untuk bertatap muka, sifat yang tertutup, dan perasaan takut untuk bercerita. Sedangkan rendahnya keterbukaan diri orangtua kepada anak karena mereka tidak ingin membebani anak dengan permasalahan mereka. Selain itu mereka juga beranggapan bahwa meskipun mereka bercerita kepada anak, anak tidak akan dapat memahami apa yang orangtua hadapi, seperti yang disampaikan oleh salah seorang informan di bawah ini:

"Enggak (tidak), karena aku sendiri kalau punya masalah mau cerita sama (dengan) anak belum tentu juga bisa nanggepi (menanggapi)". (Wawancara dengan informan 1/Pb. Tanggal $24 \mathrm{Mei}$ 
2016).

Dalam kutipan wawancara di atas menunjukkan bahwa alasan dari tidak melakukan-nya keterbukaan diri adalah karena merasa bahwa meskipun dia menceritakan permasalahan yang dia hadapai dia tidak akan memperoleh tanggapan dari lawan bicaranya. Hal ini didukung oleh pendapat Devito (2011) yang menjelaskan di dalam bukunya yang berjudul "Komunikasi Antar Manusia" bahwa ketika seseorang melakukan pengungkapan diri, maka dia mengharapkan imbalan dari pengungkapan diri yang telah dia lakukan salah satunya adalah kita akan lebih mampu atau lebih dapat menanggulangi permasalahan yang sedang kita hadapi. Sehingga apabila seseorang tidak memperoleh imbalan atas pengungkapan diri yang telah dia lakukan maka dia memilih untuk tidak melakukan pengungkapan diri. Nyatanya dengan kurangnya keterbukaan diri yang dilakukan oleh orangtua juga berimbas pada sikap terbuka pada anak, Istadi (2012) berpendapat bahwa untuk memancing anak untuk mau membuka diri maka diperlukan adanya sikap keterbukaan diri yang ditunjukkan oleh orangtua. Hal tersebut dilakukan agar anaknya merasa dihargai karena telah dipercaya untuk mendengar rahasia dari orangtuanya dan selanjutnya mereka akan menjadi lebih mudah untuk membuka diri satu sama lain. Selain dengan melakukan keterbukaan diri, orangtua juga dapat memancing anak untuk curhat dengan cara mencari umpan pembicaraan dari hal yang disukai oleh remaja serta menciptakan rasa aman dan nyaman. Terkait tentang openness Guerrero, Andersen, dan Afifi menjelaskan bahwa kejujuran adalah unsur paling penting dalam menjaga kesehatan ataupun kedekatan di dalam suatu hubungan (Guerrero, Andersen, \& Afifi, 2004). Donges (2015) menambahkan bahwa ketika anak mulai menutup diri dan tidak mengungkapkan perasaan dan pikirannya kepada orangtua maka tidak akan terjalin komunikasi yang aktif sehingga dapat menjadi pemicu anak dalam melakukan kenakalan remaja. Pendapat ini juga didukung oleh Willis
(2005) yang menjelaskan bahwa tidak adanya rasa aman akan menjadi sumber timbulnya ketegangan dan kekecewaan, sehingga akan memicu terjadinya kenakalan remaja.

Berdasarkan hasil penelitian ini, meskipun orangtua tidak melakukan keterbukaan diri kepada anak namun orangtua melakukan upaya dalam memancing anak untuk bercerita kepada meraka atau melakukan keterbukaan diri. Salah satu upaya yang dilakukan oleh orangtua agar anak mau melakukan keterbukaan diri yaitu dengan mengajak anak untuk bercanda sehingga anak merasa nyaman, sehingga dengan sendirinya anak akan mulai mau bercerita. Cara lain yang digunakan oleh orangtua untuk memancing anak bercerita adalah dengan cara melihat isi pesan yang ada di handphone milik anak dan ketika menemukan sesuatu yang dirasa kurang pasakan ditanyakanlangsung kepada anak. Hal-hal tersebut mereka lakukan agar mereka tahu apa saja yang terjadi pada anak, sehingga ketika anak melakukan sesuatu yang salah maka orangtua dapat mengetahui dan memperingatkan anak agar tidak terjerumus.

Sedangkan dalam perilaku routine talk antara anak dan orangtua terjalin dengan baik. Seperti yang diungkapkan oleh Maryanti dan Rosmiyani bahwa komunikasi yang baik dapat dilakukan dengan komunikasi tidak langsung, misal lewat telepon, SMS, surat menyurat sehingga dapat menambah keeratan hubungan antara anak dan orangtua, karena dengan melakukan hal tersebut dapat menunjukkan kepada anak tentang kepedulian dari orangtua. Dapat juga berupa ungkapan kasih sayang, ataupun dengan menanyakan kabar (Maryanti \& Rosmiani, 2007). Dalam penelitian ini meskipun informan memiliki kendala untuk saling bertatap muka, namun mereka dapat mengatasinya dengan menggunakan alat komunikasi handphone, seperti yang diungkapkan oleh salah satu infoman:

"Setiap saat, selalu, minimal 2 kali. Harus itu pasti, pagi sama(dengan) 
sore biasanya. Kalo (kalau) pagi itu mengingatkan bangun, solat, makan, sekolah, kalo (kalau) sore, kamu dimana, udah (sudah) makan belum, dan lainlain".(Wawancara dengan informan 3/ Pb. Tanggal 6 Juni 2016).

\section{Assurances (Jaminan Komitmen)}

Assurances adalah perilaku komunikasi yang dilakukan dengan memberikan jaminan mengenai komitmen mereka misalnya dengan saling memperhatikan. Berdasarkan hasil penelitian menunjukkan bahwa dalam hal memberikan perhatian bukan hanya dari orangtua saja yang melakukannya, namun anak juga memberikan perhatian kepada orangtua mereka. Bentuk perhatian orangtua yang ditujukan kepada anak misalnya dengan memperhatikan lingkungan pertemanan anak, hal tersebut untuk mengantisipasi anak agar tidak terjerumus ke hal-hal yang tidak diinginkan, selain itu orangtua juga kerap menanyakan kabar anak. Hal ini ternyata dapat menambah keeratan hubungan antara orangtua dan anak, seperti yang disampaikan oleh Maryanti dan Rosmiani bahwa komunikasi yang baik dapat menambah keeratan hubungan yang terjalin antara orangtua dan anak, misalnya dengan memberikan ungkapan kasih sayang maupun menanyakan kabar (Maryanti \& Rosmiani, 2007). Karena dengan terjadinya perceraian akan membuat anak merasa tidak memperoleh perlindungan dan kasih sayang dari orangtuanya (Ningrum, 2013; Prihatinningsih, n.d). Selain itu baik anak ataupun orangtua tidak pernah mengabaikan satu sama lainnya, karena anak berpendapat bahwa dia tidak mungkin dapat mengabaikan orangtua. Di sisi lain orangtua pun mengungkapkan alasan yang serupa bahwa mereka tidak akan dapat mengabaikan anaknya sendiri. Sedangkan bentuk perhatian anak kepada orangtua biasanya menanyakan apakah orangtua mereka sudah makan atau belum. Minimnya waktu untuk saling bertapap muka tidak menjadi kendala yang berarti dalam hal saling memberi perhatian antara orangtua dengan anak, karena mereka menggunakan media komunikasi handphone untuk menanggulangi kurangnya waktu bertemu. Seperti yang disampaikan oleh salah satu informan di bawah ini:

"Pernah mbak tapi jarang, kayak aku SMS wes maem durung, Be (misalnya aku SMS sudah makan atau belum, Yah)". (Wawancara dengan informan 2/ Pc. Tanggal 24 Mei 2016).

Dari kutipan di atas menunjukkan bahwa antara orangtua dan anak memberikan perhatian satu sama lainnya. Berdasarkan penelitian oleh Shundy (2015) bahwa ketika orangtua kurang memberikan perhatian kepada anaknya maka akan berdampak pada kurangnya pengawasan terhadap aktivitas yang dilakukan oleh anak. Namun dalam penelitian ini menunjukkan bahwa orangtua memberikan perhatian sekaligus mengawasi aktivitas anaknya. Pentingnya assurances di dalam sebuah hubungan juga diungkapkan oleh Daiton, Stafford, dan Canary karena memiliki keterkaitan yang kuat dengan kepuasan di dalam hubungan. Daiton memperjelas hal itu dengan menyatakan bahwa ketika patner kita menggunakan level yang tinggi lebih dari pada yang kita harapkan pada perilaku assurances dan positivy maka kita akan lebih puas terhadap hubungan yang kita jalani (Guerrero, Andersen, \& Afifi, 2004).

\section{Task and sharing (Pembagian Tugas)}

Task and sharing adalah perilaku pemeliharaan hubungan dengan mengerjakan pekerjaan rutin yang dilakukan dengan bersama-sama. Berdasarkan hasil wawancara dan observasi diperoleh hasil bahwa salah satu informan orangtua mengungkapkan apabila alasan dia tidak meminta anaknya untuk berbagi pekerjaan rumah karena menurutnya anak sudah lelah dengan apa yang dilakukannya di sekolah, sehingga dia tidak ingin membuat anak menjadi kelelahan karena harus mengerjakan pekerjaan rumah. Selain itu rendahnya perilaku task and sharing antara orangtua dan anak didasari oleh adanya keterbatasan waktu untuk bertemu antara satu sama lain. Seperti yang dijelaskan oleh 
Guerrerro, Andersen, dan Afifi di dalam bukunya yang berjudul "Close Encounter" (2004) bahwa saling berbagi pekerjaan semisal mencuci piring hanya dapat dilakukan dalam keadaan saling bertatap muka. Meskipun demikian orangtua sekali waktu menyuruh anak mereka untuk membantu mengerjakan pekerjaan rumah misal mencuci piring atau menyapu rumah. Seperti yang diungkapkan oleh salah satu informan di bawah ini:

"Ya, bersihin rumah, masak, gantigantian". (Wawancara dengan informan 6/Pd. Tanggal 23 Juni 2016).

Dari kutipan diatas, menunjukkan bahwa antara orangtua dengan anak melakukan perilaku task and sharing walaupun mereka tidak memiliki banyak waktu untuk melakukan hal tersebut. Canary, Stafford, dan Guerreo dalam (Guerrero, Andersen, \& Afifi, 2004) menuliskan bahwa ketika dalam menjalin hubungan terjadi saling berbagi pekerjaan maka mereka akan merasa lebih dekat antara satu sama lain dan akan merasa lebih puas dengan hubungan yang mereka jalani. Kepuasan dalam sebuah hubungan, seperti yang dijelaskan lebih lanjut oleh Guererro (2004) bahwa ketika seseorang merasa puas dengan hubungan yang dijalani sama halnya dengan ketika dia merasa senang dalam menjalani hubungan tersebut.

\section{Supportiveness (Dukungan)}

Supportiveness adalah perilaku pemeliharaan hubungan dengan saling memberikan dukungan dan dorongan. Di dalam penelitian ini perilaku pemeliharaan hubungan supportiveness tidak hanya dilakukan oleh orangtua saja, namun peneliti menemukan bahwa anak juga memberikan dukungan serta dorongan kepada orangtua mereka. Dukungan yang dilakukan oleh orangtua cenderung mengenai proses belajar, alasan orangtua memberikan dukungan dan dorongan kepada anak adalah untuk meningkatkan prestasi yang telah diraih oleh anak, selain itu agar anak merasa bangga terhadap diri mereka sendiri dan beranggapan bahwa dia mampu melakukan sesuatu hal. Sedangkan dukungan dan dorongan yang diberikan oleh anak kepada orangtua lebih kepada semangat untuk terus berkerja dan memperoleh pengahasilan. Seperti yang disampaikan oleh salah seorang informan:

"Ya, ya kalau didukung dia pasti akan merasa lebih bangga dan jadi lebih pede (percaya diri), selagi tujuan dia itu positif. Kalau punya ini nggak (tidak) didukung itu nggak (tidak) didukung kan nanti jadi nakal kan orangnya". (Wawancara dengan informan 3/ Pe.Tanggal 6 Juni 2016).

Dari kutipan di atas menunjukkan bahwa orangtua dan anak saling memberikan dukungan satu sama lain. Dalam penelitian ini dukungan dan dorongan yang diberikan memberikan efek kepada yang lain, ketika orangtua memberikan dukungan kepada anak untuk lebih giat belajar maka anak akan merasa lebih semangat untuk belajar dan anak juga akan merasa lebih percaya diri dan bangga pada dirinya. King dalam (Kumpfer \& Alvarado, 1997) mengungkapkan bahwa pemberian dukungan kepada anak dapat mengurangi kenakalan dan penggunaan narkoba. Hal ini berkaitan dengan penelitian yang dilakukan oleh Fagan dan Chruchill (2012) yang menjelaskan bahwa anak yang berada di dalam keluarga yang bercerai memperoleh lebih rendah dukungan dibandingkan anak yang berasal dari keluarga yang utuh. Bahkan Kumpfer dan Alvarado (1997) menambahkan di dalam jurnalnya bahwa secara umum pendekatan dengan dukungan dari orangtua lebih efektif daripada pendekatan yang sangat terstruktur, seperti pelatihan perilaku orangtua, pelatihan keterampilan keluarga, terapi keluarga, atau program dukungan keluarga luas.

\section{Joint activities (Kegiatan Bersama)}

Joint activities adalah perilaku pemeliharaan hubungan yang berkaitan dengan menghabiskan waktu bersama antara orangtua dan anak. Berdasarkan hasil wawancara yang peneliti lakukan menunjukkan bahwa antara orangtua 
dan anak menghabiskan waktu bersama walaupun dengan frekuensi yang rendah. Mereka jarang untuk bisa keluar dan menghabiskan waktu bersama dan hal tersebut didasari oleh rendahnya waktu mereka untuk bertemu. Orangtua dan anak mengungkapkan bahwa alasan mereka jarang menghabiskan waktu bersama terutama karena adanya kesibukan masingmasing. Namun meskipun demikian ketika orangtua dan anak memiliki waktu senggang maka mereka akan mempergunakannya sebaik mungkin dengan pergi ke tempat wisata, berbelanja bersama, ataupun hanya sekedar makan di luar. Seperti yang dikutip di dalam pernyataan berikut dari salah seorang informan:

"Ya keluar bareng (bersama) mbak, misal pergi ke umbul-umbul. Kan tempatku deket sama (dengan) umbul-umbul, pokoknya air-air gitu. (.....) juga sukanya di tempat seperti itu". (Wawancara dengan informan 1/Pf. Tanggal $24 \mathrm{Mei}$ 2016).

Berdasarkan penelitin yang dilakukan oleh beberapa peneliti (Egland, et al, 1994; Reisman, et al, 1993) yang sepakat berpendapat bahwa banyaknya waktu yang dihabiskan bersama dengan patner juga berhubungan positif dengan kepuasan. Dengan menghabiskan waktu bersama menciptakan perasaan persahabatan, kepaduan, dan menjadi sarana terbukanya komunikasi (Guerrero, Andersen, \& Afifi, 2004). Sedangkan Widayanti mengungkapkan bahwa dengan menghabiskan waktu bersama maka anak merasa bahwa dirinya dibutuhkan dan diperhatikan oleh orangtuanya (Widayati et al., n.d.). Selain itu lebih lanjut Canary, Stafford, dan Guerrero mengungkapkan bahwa dengan adanya perilaku joint activities dapat juga memunculkan perasaan kebersamaan dan persamaan (Guerrero, Andersen, \& Afifi, 2004).

\section{Humor (Kelucuan)}

Humor merupakan perilaku pemeliharaan hubungan yang berkaitan dengan penggunaan panggilan lucu ataupun tertawa bersama-sama. Dalam perilaku pemeliharaan hubungan ini antara orangtua dan anak dapat sama-sama menjalankan peran dengan baik. Mereka dapat bekerja sama untuk membuat suasana humoris tercipta di antara mereka dengan memberikan nama panggilan yang lucu ketika berkomunikasi hingga saling melempar sindiran satu sama lain. Meskipun demikian terkadang sindiran juga digunakan oleh orangtua untuk menyampaikan kritikan kepada anak mereka, hal itu mereka lakukan demi menjaga agar anak mereka mudah untuk menerima kritikan dan tidak tersinggung ketika orangtua memberikan kritikan kepada mereka.

"Sering saling sindir, koyo cah enom buk buk (seperti anak muda, Bu)" (Wawancara dengan informan 4/Pg. Tanggal 24 Mei 2016).

Liliweri (2015) menyebutkan bahwa tujuan umum komunikasi manusia meliputi: mengirimkan informasi, menyatakan perasaan, menghibur, mendidik, dan mempengaruhi. Dia menjelaskan bahwa kita tidak bisa mengelak untuk tidak berpikiran sulit dan berperasaan buruk, sehingga dengan caranya masing-masing mengirimkan pesan yang berisi hiburan agar dinikmati oleh penerima. Dengan katakata penghiburan membuat orang menjadi lebih tenang dan merasa nyaman dalam kesehariannya. Lebih lanjut dia memberikan gambaran tentang bagaimana jika di dalam komunikasi antarpersonal kita dijejali seluruh informasi tanpa bernuansa hiburan, maka kita akan merasakan ketegangan.

\section{Constructive conflict management (Ma- najemen Konflik yang Baik)}

Constructive conflict management adalah perilaku pemeliharaan hubungan yang berorientasi pada penyelesaian konflik yang terjadi dengan baik. Konflik sendiri tidak akan pernah dapat lepas dari kata baik atau buruk, melainkan bagaimana cara kita mengelola konflik yang terjadi, bahkan ketidakcocokan dapat membuat sebuah hubungan menjadi lebih kuat ataupun melemahkan. Beberapa telaah pustaka 
terkait konflik antarpribadi mengungkapan pilihan dalam mengelola konflik, salah satunya adalah mengelola konflik dengn cara yang efektif. Mengelola konflik dengan efektif adalah inti untuk memelihara hubungan dalam keadaan sehat dan menyenangkan (Guerrero, Andersen, \& Afifi, 2004). Ketika terjadi konflik antara orangtua dan anak maka mereka memilih untuk menyelesaikan dengan baik, orangtua memilih untuk bersikap lebih bijaksana dan lebih tenang dalam mengahadapi konflik dengan anaknya. Alasan orangtua memilih bersikap lebih bijaksana dan tenang karena menurut pandangan mereka ketika anak sedangmarahdanorangtuamenanggapinya dengan kemarahan juga, maka akan memicu anak menjadi membangkang kepada orangtua. Sedangkan anak memilih untuk diam dan mendengarkan apa yang sedang dibicarakan oleh orangtua. Namun terkadang ketika orangtua menyalahkan anak tentang suatu hal dan anak merasa tidak terima dengan sikap orangtua, maka anak akan melakukan pembelaan. Ketika anak melakukan pembelaan atas dirinya, orangtua akan mendengarkan pembelaan dari anakyang selanjutnya akan memberikan penjelasan lebih mendalam mengenai alasan orangtua memarahi anak dan letak kesalahan anak yang telah diperbuat. Dengan demikian anak akan memahami letak kesalahan mereka, sehingga konflik dapat terselesaikan dan komunikasi pasca terjadinya konflik akan berlangsung seperti biasa. Seperti yang diungkapkan oleh salah seorang informan:

"Yo meneng wae, ditompo, trus nek dikandani yo di aplikasikan (Ya diam saja, terus nanti kalau diberi tahu ya diaplikasikan)" (Wawancara dengan informan 4/Ph. Tanggal 24 Mei 2016)

Telaah pustaka yang dilakukan oleh Sillars, Canary, dan Tafoya menghasilkan pendapat bahwa menurut mereka ketika konflik kelurga antara orangtua dan anak dapat ditangani dengan baik di dalam keluarga maka baik orangtua dan anak akan merasakan kepuasan terhadap hubungan yang mereka jalani (Valley \& Gilman, 2009).
Pendapat ini di dukung oleh Guererro bahwa suara yang lembut, emosi negatif yang diredam, dapat membuat hubungan menjadi lebih kuat bukan semakin melemah (Guerrero, Andersen, \& Afifi, 2004).

\section{E. PENUTUP}

Perilaku pemeliharaan hubungan antara orangtua yang bercerai yang memiliki hak asuh dengan anaknya menurut Guererro, Andersen, dan Afifi dapat dilihat dari beberapa kategorisasi, meliputi: Positivity (interaksi yang menyenangkan), Openess and routine talk (keterbukaan dan rutin berkomunikasi), Assurances (jaminan komitmen), Task and Sharing (pembagian tugas), Supportiveness (dukungan), Joint activities (kegiatan bersama), Humor (kelucuan), dan Constructive Conflict management (manajemen konflik dengan baik). Pada penelitian ini diperoleh kesimpulan bahwa baik orangtua maupun anak melakukan sebagian besar perilaku pemeliharaan hubungan. Perilaku pemeliharaan hubungan yang dilakukan antara orangtua yang bercerai yang memiliki hak asuh dengan anaknya terletak pada positivity, assurances, supportiveness, joint activities, constructive conflict management, dan humor. Sedangkan perilaku pemeliharaan hubungan antara orangtua yang bercerai yang memiliki hak asuh dengan anaknya yang tidak dilakukan meliputi: openness and routine talk serta task and sharing. Hal ini didasari dari kurangnya frekuensi tatap muka antara orangtua dan anak. 


\section{DAFTAR PUSTAKA}

Abadi, T. W., Sukmawan, F., \& Utari, D. A. (2013). Media Sosial dan Pengembangan Hubungan Interpersonal Remaja di Sidoarjo. Kanal, Vol. 2, No. Retrieved from http://journal. umsida.ac.id/files/7.FANDRIANTOTOK.pdf

Amato, P. R. (2012). The Consequences of Divorce for Adult and Children: An Update. http:// doi.org/10.5559/di.23.1.01

Estuti, W. T. (2013). Dampak Perceraian Orang Tua Terhadap Tingkat Kematangan Emosi Anak Kasus Pada Siswa Kelas VIII SMP Negeri 2 Pekuncen Banyumas Tahun Ajaran 2012/2013. Retrieved from http://lib.unnes.ac.id/19302/1/1301407045.pdf

Ariyanti, F. (2014, Maret 26). Retrieved Maret 22, 2016, from Liputan6: http://health.liputan6.

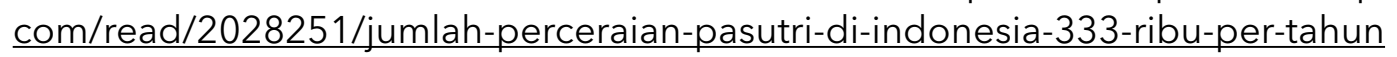

Canary, D. J., \& Dainton, M. (2003). Maintaining Relationships Through Communication: Relational, Contextual, and Cultural Variations. New York: Routledge.

Devito, J. A. (2011). Komunikai Antar Manusia. Pamulang: Karisma Publishing Group.

Donges, W. E. (2015). A Qualitative Case Study: The Lived Educational Experiences of Former Juvenile Delinquents, 20(7), 1009-1028.

Fagan, P. F., \& Churchill, A. (2012). Recognize Effects of Divorce on Children. Family Practice News, 40(18), 19. http://doi.org/10.1016/S0300-7073(10)71118-X

Fajar, Marhaeni. (2009). Ilmu Komunikasi Teori \& Praktek. Yogyakarta: Graha Ilmu.

Fraley, R. C., \& Heffernan, M. E. (2013). Attachment and parental divorce: a test of the diffusion and sensitive period hypotheses. Personality \& Social Psychology Bulletin, 39(9), 1199-213. http://doi.org/10.1177/0146167213491503

Galvin, K. M., Braithwaite, D. O., \& Bylund, C. L. (2016). Family Communication: Cohesion and Change. New York: Routledge.

Guerrero, L. K., Andersen, P. A., \& Afifi, W. A. (2004). Close Encounter. SAGE Publications, Inc. Istadi, I. (2012). Ayo Bicara. Bekasi: Pustka Inti.

Kumpfer, K. L., \& Alvarado, R. (1997). Effective Family Strengthening Interventions. Juvenile Justice Bulletin OJJDP, (November), 1-15.

Liliweri. (2015). Komunikasi Antarpersonal. Jakarta: Kencana.

Maharani, E. (2016, Maret 20). Retrieved Maret 22, 2016, from Republika: http://www. republika.co.id/berita/nasional/umum/16/03/20/o4c891335-mensos-angkaperceraian-melonjak-jatim-penyumbang-terbesar

Maryanti, Rosmiani. (2007). Keluarga Bercerai dan Intensitas Anak Terhadap Orangtuanya (Studi Deskriptif di Kecamatan Medan Sunggal.

Ningrum, P. R. (2013). Penyesuaian Diri Remaja, 1(1), 69-79.

Prihatinningsih, S. (n.d.). Jurnal Juvenile Delinquency (Kenakalan Remaja) Pada Remaja Putra Korban Perceraian Orang Tua.

Shundy, B. T. A. (2015). Pengasuhan Single Parent Pada Kasus Kenakalan Remaja. PhD Proposal, 1. http://doi.org/10.1017/CBO9781107415324.004

Sugiyono. (2013). Metode Penelitian Kuantitatif, Kualitatif, dan R\&D. Bandung: Alfabeta.

Valley, L., \& Gilman, A. (2009). The parent-child relationship in adulthood: Associations 
18 Komuniti, Vol. VIII, No. 1, Maret 2016

among Attachment, Relational Maintenance, Conflict Management, and relationship Satisfaction.

Widayati, R., Lestari, S., Ramli, A. H., Psikologi, P.S., Brawijaya, U., \& Remaja, K. (n.d.). Hubungan Keharmonisan Keluarga Dengan Kenakalan, 1-13.

Wijayanti, Y. (2009). Proses Komunikasi Interpersonal Ayah dan Anak dalam Menjaga Hubungan. E-Komunikasi, I. NO. 3.

Willis, S. S. (2005). Remaja dan Permasalahannya: Mengupas Berbagai Bentuk Kenakalan Remaja Seperti Narkoba, Free Sex, dan Pemecahannya. Bandung: Alfabeta.

Yusuf, S. (2011). Psikologi Perkembangan Anak \& Remaja. Bandung: Remaja Rosdakarya. 